\title{
Book Review: John Komlos, The Foundations of Real-World Economics: What Every Student Should Know, ISBN:978-1-138- 29654-1, Routledge, NY, 2019
}

\section{by Larry Allen, Lamar University}

If there is truth to the suggestion that 'survival of the fittest' applies to ideas as well as organisms, it is high time to evaluate how well mainstream economics is holding its ground in the decade after the 2008 financial crises. John Komlos has done this much and more in his new book, The Foundations of Real-World Economics: What Every Student Should Know. It is a new and revised edition of an earlier book with an equally revealing title, What Every Student Needs to Know and Doesn't Get in the Usual Principles Text. Komlos takes up virtually every topic in a mainstream economics principles textbook and examines them from new perspectives suggested by more recent research that can yield fresh insights. Komlos's qualifications for writing such a book are probably equal to those of any other economist of our generation. He holds two Ph.D.'s from the University of Chicago, one in economics and one in history. His experience spans two continents, having held an endowed chair at the University of Munich for eighteen years. He has an impressive publication record that addresses the most timely and significant issues of the day. He also blogs for PBS.

Komlos has written a unique and thought-stirring book that in the plainest words introduces students to alternative views on the economy not covered even in the most encyclopedic principles textbooks. Komlos calls his approach to economics 'Humanistic Economics', which puts human beings at the center of the economy rather than inanimate abstractions such as GNP. He envisions a capitalism with a human face that would produce an economy with zero unemployment, zero inflation, zero balance of payments deficits, and zero government deficit over the business cycle. He points out that the goal of the economy should be to provide people with a decent life, which means not only full employment and a steady income but also mass flourishing that the current economy is not providing. Instead, stress, uncertainty, and even despair abound, as far too many people are excluded from the American Dream. Komlos is as conservative as anyone can be who can still make the case for zero unemployment; he is also as liberal as anyone can be who can still make the case for zero budget deficits over the course of the business cycle.

For those who regard this as a counsel of perfection, keep in mind that in 2001 Switzerland, famous for financial prudence, adopted a constitution amendment that forces lawmakers to run budget surpluses in booms and balance budgets over the business cycle. Japan has an unemployment rate of $2.4 \%$ and draws very little of its labor force into the military. The United States saw a 1.2\% unemployment rate in 1944 . The point is that the 
United States should to be doing much better than it is doing, and there is a Mount Everest of evidence that it is possible, as evidenced by the large number of people who want full-time employment but either fail to search because of low expectations for success or settle for parttime employment.

At times Komlos reminds us that he is not saying anything that has not been said by philosophers dating back to Aristotle and by influential economists in the history of economic thought: 'The quest for the good life is as old as philosophy itself. Aristotle was among the first to think about it systematically around $350 \mathrm{BC}$ by arguing that the good life was about understanding the world around us.' Komlos sees in contemporary economics much talk about wealth, but not much talk about intelligently used wealth. Wealth that is wisely used provides mass flourishing rather than being frivolously used to increase conspicuous consumption at any cost, regardless of its environmental damage or the burden on future generations. Society busies itself making sure that government does not interfere with its ability to make wealth. It gives scant thought, however, to how to use wealth to improve quality of life. The more wealth that is created, the more important it is to find the most intelligent uses that support sustainability and create the proper social environment for a dignified life. Komlos exhibits a fine sense of the difference between ideals that elevate people and those that do not.

Keynes himself could not ignore the subject of the good life. Komlos quotes from Keynes' The End of Laissez Faire: The Economic Consequences of Peace (1926): "I think that capitalism, wisely managed, can probably be made more efficient for attaining economic ends than any alternative system yet in sight, but that in itself is in many ways extremely objectionable. Our problem is to work out a social organization which shall be as efficient as possible without offending our notions of a satisfactory way of life." Komlos observes that things did not turn out the way Keynes expected, referring to Keynes' prediction that his generation's grandchildren would only work 15 hours per week. Instead too many of us are working with uncertain incomes, all the while working well in excess of 60-hour weeks just to keep afloat.

Economists went overboard in exaggerating the role of Adam Smith's invisible hand, a metaphor which emphasizes that selfishness serves a common good - an idea coldly restated in modern culture in the phrase 'Greed is good' from the 1987 movie Wall Street. Komlos believes that whitewashing greed as useful underestimates the value of social impulses which also serve a valuable purpose. Society is not a little strengthened by confidence in the fairness of the economic system, and more than a little damaged by the risky excesses fueled by greed, which usually means rent seeking, and hurts others by devious means and by gaming the system. Komlos mischievously cites none other than Adam Smith's Theory of Moral Sentiments (1759) to make his point in a footnote: 'How selfish....man may be supposed, there are evidently some principles in his nature, which interest him in the fortune of others, 
and render their happiness necessary to him, though he derives nothing from it except the pleasure of seeing it.' The Nobel Prize winner Joseph Stiglitz quipped that the "invisible hand is often invisible because it is not there." He meant, of course, that the invisible hand does not work properly in the presence of asymmetric information, a point almost always forgotten in principles courses.

In fact, one of the main advantages of Komlos's book is that it lucidly covers many important topics that are neglected in conventional textbooks, such as asymmetric information. The newer research is not automatically drawn into the mainstream canon since textbook publishers and economic researchers have different aims. Newer research is more likely to disturb and undercut the generalizations emphasized and marketed in mainstream textbooks. These include not only imperfect information but such topics as the Easterlin paradox, hyperglobalization, path dependence, and the importance of economic power in shaping the course of political events. Money is power and the increase in inequality has brought about a lopsided nature of political power that goes unmentioned in mainstream economics. Thus, a whole chapter of the book is devoted to the financial crisis. Overconfidence in free markets led to rationalizations of incautious behavior. The failure to bail out Main Street fueled the fire of discontent that ended up in the unexpected election of Donald Trump as the President of the United States. These developments are missing in most mainstream textbooks, even at the intermediate and advanced levels.

The book stresses the role of asymmetric information, and how the market system enriches some at the expense of others when some groups have access to better information. In real world economics, buyers and sellers look for transactions where they know something which the other party to the transactions does not know, undercutting the basis for the efficiency of free markets. Stiglitz, Akerlof, and Spence have shown this a long time ago, but this basic insight is still missing from most mainstream textbooks. Undergraduate students know this because they hear it in lines of a well-known country song: "You've got to have an ace in the hole, / a little secret that nobody knows." Looking for transactions with asymmetric information becomes a virtual mania in financial markets. The rise of the free market sun went so far in mainstream textbook economics as to inspire the development of the efficient market hypothesis, which purports to explain prices in one of the most psychological and emotional markets of all, the stock market. Komlos quotes another Nobel Prize winning economist, Robert Shiller: "the so-called efficient market hypothesis ... is one of the most remarkable errors in the history of economic thought."

One facet that drives the book to unusual heights of excellence and suggestiveness touches on the fundamental nature of human beings. A chapter entitled "Homo Oeconomicus is Extinct: The Foundations of Behavioral Economics" opens with a quote from the Roman poet Ovid: "I see the Right, and approve it too, / Condemn the wrong — and yet the wrong pursue." Economics assumes a species of human beings that more nearly describes a vision of a deity 
held by the most advanced philosophical minds. Psychologists and biologists laugh at economists' ideas of human decision-making and optimizing behavior. Human beings vary too much in ability and adaptability in order to optimize utility in a rapidly transforming economic landscape. This is particularly true if the market is populated by marketers who understand unconscious thought processes far better than consumers do. Komlos buttresses his argument in suggestive sub-chapters. These includes sections on Neuroeconomics; Bounded Rationality; Satisficing instead of Optimizing; Biases and Wonders of Intuition; Heuristics; Framing, Accessibility, and Anchoring; Prospect Theory, Behavioral Economics; Cognitive Endowment; and Genetic Endowment. The chapter is well documented, including a footnote quoting the famous Cambridge Economist Joan Robinson: "utility maximization is a metaphysical concept of impregnable circularity."

Komlos voices skepticism about the achievements of mathematical economics. It produces mathematical analysis of unquestioned originality, but it is better at proving that certain conditions and results are possible on academic blackboards than at proving that they actually exist in the real world. Important economic phenomena are too subtle and elusive to be caught in a formula. He puts his faith in a scope and depth of empirical data that transcends the bounds of economic theory. His figures and tables report data on everything from life expectancy at birth and physicians per 1000 population to U.S homicide rate per capita and the ratio of the top $90 \%$ of the disposable income distribution to the bottom $10 \%$. Figures and tables also report the usual data, the consumer confidence index, velocity of circulation of M1, national debt as a percent of GDP, real GDP and potential GDP, and so on.

With this "Humanistic Economics" approach, Komlos addresses the economic issues of the day. He heaps scorn on supply-side economics, underscoring the inconvenient truth that the decades of the 1950's and 1960's boasted both higher marginal tax rates and higher economic growth. He attributes anemic growth to neglect of education, basic research, and infrastructure. Even if supply-side economics is credited with high rates of technological advance, a correlation some might argue, the costs may exceed the benefits. In the beginning it creates as many losers as winners and creates new opportunities for the fast learners to exploit the slow learners.

$\mathrm{He}$ also shows little confidence in the benefits of pure competition. Even in highly competitive agricultural markets, for instance, some farmers end up owning much more land than other farmers. Other competitive markets become imperfectly competitive over time, giving sellers an advantage. As confidence in free markets became more firmly established in the 1980 's, the frequency of financial crises increased. Economists are in denial about how many markets the government must regulate to avoid disaster. He takes on the American Medical Association for restricting the number of doctors in the name of raising quality. As a result, the number of doctors per capita is significantly lower in the U.S. than in most, if not all, Western European countries and Canada. In life expectancy at birth, the U.S. ranks a low 
$31^{\text {st }}$ in the world while health care expenditures per capita are nearly twice the median of developed countries.

Komlos sees the unemployment rate the center of many complexities in macroeconomics. In Chapter 11 he anticipates the current skepticism about the natural rate of unemployment, observing a tendency of the Federal Reserve to adjust estimates of the natural unemployment rate in order to keep it a viable concept. Here again we see a difference in the way Komlos covers a subject compared to mainstream textbooks, which tend to accept the unemployment rate is an objectively derived number published by government agencies. It happens that this official measure does not count discouraged workers as unemployed: that is, people who want to work but have not recently applied for jobs. It ignores the fact that applying for jobs may not be easy for someone living in town where the largest and best-paying employer just closed its doors, and there are ten job seekers for every job vacancy. Not to mention the fact that in this situation the available jobs are likely to pay much less than the jobs lost, and employers already have more applicants than they want. If this individual accepts a part-time job, they are officially counted as fully-employed even though they need and want a full-time job.

In a bid to pursue the goal of a zero-trade balance, Komlos departs even further from the mainstream. In Chapter 13 he endorses a proposal from Warren Buffet's suggestion that the U.S. government issue import certificates to exporting firms in an amount equal to the value of their exports. U.S. importers or their foreign suppliers would have to purchases the certificates to sell foreign goods in U.S. markets. It would end the current debilitating trade pattern in which the U.S. sells assets in return for consumables. Exporters would earn income by selling the import certificates and foreign countries could not retaliate. On the contrary, they would be incentivized to buy more from the U.S. so they could sell more to the U.S. This policy would create some 2.5 million jobs in the U.S. without the need for a trade war.

Komlos takes the case of Brooksley Born to reveal a policy arrogance born of a trendy confidence in free markets, confidence in the blind mechanism of economic models, and the intoxication with technological and financial innovation. In 1998 Brooksley Born was Chair of the Commodities Futures Trading (CFTC.) She recommended to Congress that the government should subject credit default swaps to regulation. She stood unmoved by assurances from heavyweights like Alan Greenspan and Robert Rubin that regulations were unnecessary. Greenspan and Rubin decided the problem must be that Brooksley Born was unreasonable, stubborn, and irascible. She was unsuccessful and resigned in frustration. President Bill Clinton also ignored her pleas.

That this type of thinking led to the financial crisis has not gone unnoticed, nor the inability of mainstream economics to learn from the crisis. The Washington Post recently 
published an article, "It's time we tear up out economics textbooks and start over" in which Komlos's textbook is cited as an antidote to mainstream economic textbooks such as the ones written by Gregory Mankiw, who pays too little attention to imperfect markets, oligopolistic firms, and less than perfectly rational market participants. These Panglossian treatments of economics discourage expectations of a crisis, and when a crisis does occur, they give no reason why it should ever happen again.

Komlos finds wholly inadequate the mainstream treatment of wages as determined by marginal product. Too many wage differences cannot be justified by the theory. The tendency of economics to shun income inequality issues is revealing in itself. Komlos sees it as an issue that must be tackled. He makes the case for the ideas of John Rawls who argued that the just society is one in which individuals would choose to join even without knowing in advance what their own socio-economic status would be or even what their individual endowments would be. All boats may rise with the tide, but as things stand now society cannot buy economic security with a rising tide of wealth. That would require government intervention, which in turn would mess up the system. This tide leaves too many boats stranded. Komlos observes that nations ranking higher than the United States in happiness indices have higher tax rates and universal healthcare coverage, easing many anxieties. He examines the happiness data and cites the paradox of declining happiness of women amid rising incomes and empowerment. He quotes Warren Buffet saying: "There has been class warfare going on for the last 20 years, and my class won." U.S. income inequality began stridently widening in the 1980's, about the same time that questioning free-market outcomes became taboo.

In a concluding chapter Komlos focuses on 14 headwinds faced by the U.S. economy, including endemic budget deficits, burgeoning private debt, negligible saving rates, large trade deficits in goods and services, dependence upon Chinese financing of the national deficit, costly military commitments, mediocre primary and secondary education (and expensive college education), dilapidating infrastructure, and global warming. One of the headwinds is mainstream macroeconomics theory, which seems unable to develop creative and convincing responses to these headwinds.

This book has its flaws. Komlos loses his dispassionate candor when pointing the finger of suspicion at various policy makers over the financial crisis. Talk of zero unemployment and zero government deficits is a counsel of perfection. Exceptions disturb every generalization in economics, including those in this book. He loses patience with mainstream textbooks but perhaps publishers are justified in favoring textbooks that emphasize the theoretical rationales for existing economic policies, even though some of the policies are bound to be proven mistaken in the future. The long-term benefits of technological advancement must outweigh

$1 \quad$ https://www.washingtonpost.com/opinions/its-time-we-tear-up-our-economics-textbooks-and-startover / 2019/06/23/54794ab8-9432-11e9-b570-6416efdc0803 story.html?utm term=.817a1c19201d 
the immediate disadvantages. Technological advancements enlarge our means without improving our purposes. It takes time for the purposes to catch up. For example, industrialization brought the exploitation of women and children before it brought the 40-hour work week.

It would be unfair, however, to think that these flaws subtract from the real value of the book. This is an intelligent and thought-stirring book, one written with a serious purpose and accessible to all educated readers. It puts muscle into the defense of ideas that have no strong interest groups to champion them. The attentive reader will find it rich in ideas and in inspiration. 